\title{
„Népünk dicső győzelme” \\ Adalékok az 1954. évi csehszlovákiai parlamenti választások történetéhez ${ }^{1}$
}

\author{
Popély Árpád
}

\begin{abstract}
„The Glorious Victory of our People” Additions to the History of the Czechoslovak Parliamentary Elections in 1954

Abstract

The study focuses on the parliamentary elections of the communist Czechoslovakia in 1954. After World War II this was the first election in which not only the Hungarian minority was allowed to take part, but candidates of Hungarian nationality were also elected in the Parliaments of Prague and Bratislava. From then on, until the change of regime in 1989, the Hungarian minority was constantly provided seats in both Parliaments. However, the Hungarian MPs were not elected by the Hungarian community, but like other worker-peasant representatives, were chosen and brought to Parliament by the communist party. Their charge was to demonstrate the "proper" nationality policy of the communist party. Opportunities to stand for Hungarian minority interests were almost none.
\end{abstract}

Keywords: Czechoslovakia; parliamentary elections; Hungarian minority; communist party

Kulcsszavak: Csehszlovákia; parlamenti választások; magyar kisebbség; kommunista párt

Subject-Affiliation in New CEEOL: History - Recent Histoty - Post-War Period DOI: 10.36007/eruedu.2021.4.18-30

Az 1948-ban megválasztott prágai Nemzetgyülés és a pozsonyi Szlovák Nemzeti Tanács (SZNT) mandátuma hat évre szólt, 1954-ben érkezett tehát el az ideje az új törvényhozó szervek megválasztásának. A második világháború utáni években számos jogfosztó intézkedéssel sújtott, többek között választójogától is megfosztott ${ }^{2}$ csehszlovákiai magyarság számára az 1954 novemberében megtartott választások különös jelentőségét az adta, hogy parlamenti választásokon a háború óta első alkalommal járulhatott az urnákhoz, s magyar nemzetiségü képviselőket is első alkalommal választottak be a két törvényhozásba. Az SZNT-nek 1954 tavasza óta Árvay József és Bitter László személyében volt ugyan két magyar nemzetiségü

1 A tanulmány a 1/0163/19 számú „Rôzne podoby slobody v totálnom štáte - politický život, náboženstvo, turizmus a média v (Česko)Slovensku, Mad'arsku a Východnej Európe 1938-1968” (A szabadság különböző formái a totális államban - politikai élet, vallás, turizmus és média (Cseh) Szlovákiában, Magyarországon és Kelet-Európában 1938-1968) VEGA kutatási program keretében készült.

2 A háború utáni magyarellenes jogszabályok jegyzékét Id. Popély 2014, 166-181. 
képviselője, ők azonban nem választások során, hanem behívás útján jutottak parlamenti mandátumhoz. ${ }^{3}$

A kommunista hatalomátvétel utáni második parlamenti választások előkészitése 1954 tavaszán kezdődött. A Nemzetgyűlés 1954. május 26-án fogadta el a nemzetgyülési és a szlovák nemzeti tanácsi választásokról rendelkező 26/1954. számú alkotmánytörvényt, amely a korábbi arányos helyett a többségi választási rendszert vezette be, egymandátumos választókerületeket hozott létre azzal, hogy minden 35 ezer lakosra jusson egy választókerület, s első ízben rögzítette, hogy a képviselőjelölteket a Nemzeti Front jelöli. ${ }^{4}$ A Nemzetgyülés ugyanezen a napon elfogadott 27/1954. számú, valamint az SZNT 1954. június 4-i 7/1954. számú választási törvénye - a korábbi választási törvényekkel ellentétben, amelyek csak a cseh, szlovák és más szláv nemzetiségüek számára tették lehetővé a választási részvételt - kimondta azt is, hogy nemzetiségre való tekintet nélkül választójoggal rendelkezik valamennyi 18. életévét betöltött csehszlovák állampolgár, képviselönek pedig valamennyi választójoggal rendelkező 21 . életévét betöltött csehszlovák állampolgár megválasztható. ${ }^{5}$

A 26/1954. számú alkotmánytörvény rendelkezései szerint a választások napját legkésőbb 60 nappal a választások megtartása előtt ki kellett tüzni. A prágai kormány ennek megfelelően 1954. szeptember 21-én a választások napját 1954. november 28-ára, vasárnapi napra tűzte ki, egyúttal kinevezte a nemzetgyűlési választások központi választási bizottságát. ${ }^{6}$ Másnap a szlovákiai végrehajtó szerv szerepét betöltő Megbízottak Testülete kinevezte a szlovák nemzeti tanácsi választások központi választási bizottságát, amely egyben a nemzetgyülési választások szlovákiai választási bizottságának a tisztségét is ellátta. ${ }^{7}$

Az alkotmánytörvény szerint a képviselöjelölteket ugyan a Nemzeti Front jelölte, a képviselőjelöltek kiválasztása, mint ahogy az egész választás előkészítése, valójában a prágai és a pozsonyi kommunista pártközpontban történt. A kommunista pártvezetés döntött nemcsak a kommunista, hanem a többi párt képviselöinek és a pártonkívüliként megválasztandó képviselőknek a számáról és személyéről is. ${ }^{8}$ A Nemzetgyülés csehországi képviselőiről Csehszlovákia Kommunista Pártja (CSKP) Központi Bizottságának Politikai Irodája, a Nemzetgyűlés szlovákiai képviselőiről és az SZNT képviselöiröl Szlovákia Kommunista Pártja (SZLKP) KB Irodája ${ }^{9}$ határozott, de a végső szót természetesen ez utóbbi esetekben is a prágai pártvezetés mondta ki.

3 A szlovák parlamentbe 1954 tavaszán behívott harmadik magyar képviselő, Nagy István nem egészen egy hónappal képviselői esküjének letétele után, 1954. május 23-án elhunyt.

4 Sbírka zákonů Republiky československé. Ročník 1954, částka 15., 89.

5 Sbírka zákonů Republiky československé. Ročník 1954, částka 15., 90-96.; Zbierka zákonov Slovenskej národnej rady. Ročník 1954, čiastka 6., 33-40.

6 Új Szó, 1954. szeptember 24. A Csehszlovák Köztársaság kormányának a Nemzetgyülésbe és a Szlovák Nemzeti Tanácsba való választások napjának kitűzéséröl szóló határozata, 1.

7 Új Szó, 1954. szeptember 25. A Megbízottak Testületének határozata a Szlovák Nemzeti Tanácsba való választások központi választóbizottságának megalakításáról, 1.

8 A pártállami években Csehszlovákiában a kommunista párton kívül négy ún. szatelitpárt is müködött, amelyek azonban önálló politikát nem folytathattak, s teljes egészében a kommunista párt ellenőrzése alatt álltak. A cseh országrészekben ilyen volt a Csehszlovák Szocialista Párt és a Csehszlovák Néppárt, Szlovákiában pedig a Szlovák Megújhodás Pártja és a Szabadságpárt.

9 A CSKP KB Elnöksége - szovjet mintára - 1954 nyarán vette fel a „Politické byro”, azaz Politikai Iroda megnevezést. Az SZLKP KB Elnöksége ugyanekkor a „Byro”, vagyis Iroda megnevezést kapta. 
A képviselőjelöltek - illetve valójában a leendő képviselök - kiválasztásának folyamata a következőképpen zajlott: első körben mind a prágai, mind pedig a pozsonyi pártvezetés megfogalmazta a Nemzetgyülés, illetve az SZNT választókerületeire, a két parlament politikai, szociális és nemzetiségi összetételére vonatkozó irányelveket, s összeállította azoknak a vezető funkcionáriusoknak a jegyzékét, akik számára feltétlenül helyet kivánt biztositani az egyik vagy a másik törvényhozásban. Az irányelveket és a névsort megküldték a kommunista párt kerületi bizottságai, valamint a „szatelitpártok” vezetése számára, amelyek ezek alapján felterjesztették a két pártközpontba az egyes választókerületekben indítani javasolt képviselöjelöltek jegyzékét és részletes életrajzát. Ezt követően a pártvezetés, a kerületi pártszervek és a „szatelitpártok” addig egyeztettek a jelöltekröl, amíg azok mindegyike meg nem szerezte a pártvezetés jóváhagyását.

A jelöltek kiválasztása, néhány utólagos módosítástól eltekintve, 1954 szeptemberében megtörtént. Az SZLKP KB Irodája által jóváhagyott képviselöjelöltek, illetve leendő képviselök között összesen 22 magyar nemzetiségü volt. A 368 fös Nemzetgyülésbe kilenc, a 104 fös SZNT-be pedig összességében tizenhárom magyar nemzetiségü képviselőjelölt indítását határozták el. A magyar jelöltek a hatalom követelményeinek megfelelően gyakorlatilag kivétel nélkül munkás- vagy parasztszármazásúak, a magyar lakosság foglalkozási struktúrájából adódóan pedig nagy többségükben valamely egységes földműves-szövetkezet (efsz) dolgozói, gyakran a szövetkezet elnökei voltak. A Nemzetgyülés magyar képviselöjelöltjei közül Csank Jenő a gesztetei, Dobos Imre a leleszi, Pollák Lajos a felsőpatonyi, Stromp József a jánoki, Vrábel Vendel az imelyi efsz elnöke, Porubszky Béla a lekéri állami gazdaság gépésze, Szigl Mária az éberhárdi traktorállomás kombájnosa, Petrás Gabriella párkányi tanítónő volt. ${ }^{10}$ Valamennyiükröl elmondható, hogy a szlovákiai magyar közösség számára jobbára ismeretlen, a politikában járatlan személyek voltak. Az egyetlen kivételt az eredeti hivatására nézve festőművész Lőrincz Gyula jelentette, aki már a harmincas években aktív résztvevője volt mind a csehszlovákiai, mind pedig a nemzetközi kommunista mozgalomnak, 1948-1949-ben tagja volt a szlovák pártvezetés mellett létrehozott Magyar Bizottságnak, 1948 decemberében az Új Szó alapító főszerkesztője, 1949 márciusában a Csehszlovákiai Magyar Dolgozók Kultúregyesületének, a Csemadoknak az alapító elnöke lett, 1953-ban pedig helyet kapott az SZLKP KB-ban is (Pešek 2003, 212-215).

A nemzetgyűlési képviselőjelöltekéhez hasonló volt az SZNT magyar jelöltjeinek a foglalkozási struktúrája is. Brandics András a mokcsakerészi, Janó Károly a kiskoszmályi efsz elnöke, Tóth Imre a kenyheci efsz könyvelöje, Pongrácz Frigyes a szentmihályfai efsz agronómusa, Berta János a leleszi efsz traktorosa volt, Vida Irma az érsekkétyi efsz-ben dolgozott. Árvay József a nagymegyeri állami gazdaság referense, Szeifert Ferenc a bajcsi állami gazdaság kombájnosa, Prokos József az egegi traktoros brigád vezetője, Török Pál pozsonyi kőműves volt, Nagy István ${ }^{11}$ a sajógömöri helyi nemzeti bizottság titkári, Trencsik János a komáromi közszolgáltatási üzem igazgatói tisztségét töltötte be. ${ }^{12}$ Az SZNT magyar képviselöjelöltjei közül

\footnotetext{
10 Slovenský národný archív, Bratislava ( a továbbiakban: SNA), Ústredný výbor Komunistickej strany

Slovenska - Predsedníctvo (a továbbiakban: ÚV KSS - Preds.), 872. k., a. j. 34.; 874. k., a. j. 36. 11 Csupán névrokona az SZNT-be 1954 tavaszán behivott Nagy Istvánnak.

12 SNA, ÚV KSS - Preds., 872. k., a. j. 34.; 874. k., a. j. 36.; 876. k., a. j. 41.
} 
a leggazdagabb munkásmozgalmi múlttal a géplakatosnak kitanult Dénes Ferenc rendelkezett, aki már a két világháború között szakszervezeti funkcionárius és különböző járási pártszervezetek titkára volt, 1952-ben pedig a Kassai Kerületi Nemzeti Bizottság alelnökévé nevezték ki (Pešek 2003, 75-78).

Miután a pártvezetés a képviselőjelöltek névsorát szeptember végén jóváhagyta, október elején országszerte kezdetüket vették a jelölögyülések, amelyeken különböző üzemek dolgozói összüzemi gyüléseken ünnepélyes keretek között elfogadták a választókerületük képviselöjelöltjére vonatkozó javaslatot. Az egyes üzemek ezzel együtt felajánlásokat is tettek. A füleki Béke bútorgyár dolgozói például azzal párhuzamosan, hogy jóváhagyták Lőrincz Gyula ajánlását választókerületük nemzetgyülési képviselőjelöltjévé, vállalták, hogy kiszélesítik a szocialista munkaversenyt, biztosítják a termelési terv egyenletes, maradéktalan teljesítését, a beépített bútor gyártásánál pedig betartják a határidőt, hogy így meggyorsítsák a lakásépítést. ${ }^{13} \mathrm{~A}$ jelölőgyűlésekröl hírt adó sajtó mindeközben természetesen igyekezett azt sugallni, mintha az egyes képviselöjelöltek a dolgozók spontán jelöltjei, nem pedig elöre kijelölt és a pártvezetés által jóváhagyott személyek lennének.

A közelgő választások alkalmából 1954. október közepén a CSKP KB, az SZLKP KB és a Nemzeti Front is felhívással fordult az ország lakosságához. Ezekben gyakorlatilag a választópolgárok erkölcsi kötelességévé tették a választási részvételt és a Nemzeti Front jelöltjeinek a megválasztását, mivel ezzel úgymond a kormány békepolitikájára, a világbéke megszilárdítására, a nemzetközi feszültség enyhítésére, családjuk boldog életére, a nép jólétének emelésére, a népi demokratikus rendszer megszilárdítására és az ország további felvirágzására fognak szavazni. Amint azt a CSKP KB felhívása megfogalmazta, a választások napjának „a párt, a kormány és a nép megbonthatatlan egységének hatalmas hazafias manifesztációjává” kell válnia, leszögezve egyúttal azt is, hogy „,a köztársaság minden egyes becsületes és hű polgára a Nemzeti Arcvonal jelöltjeit választja a nemzetgyülésbe". ${ }^{14}$

Az ország csaknem valamennyi településén agitációs központok létesültek, amelyek feladata a választási törvény, a jelöltek és a választások jelentőségének a megismertetése volt a választópolgárokkal. Az agitációs kampányba és a választók mozgósításába az egyes társadalmi és tömegszervezeteknek is aktívan be kellett kapcsolódniuk. A sajtó szinte naponta hozta a hírt például a Csehszlovák Békevédők Bizottsága, a Csehszlovák-Szovjet Baráti Szövetség, a Politikai és Tudományos Ismeretterjesztő Társaság, a hadsereg, a Csehszlovák Ifjúsági Szövetség vagy akár a Csemadok és annak népi együttese, a Népes által szervezett, kultúrmüsorral egybekötött előadásokról, amelyeken többek között a választások jelentőségét, a jelölteket és a népi demokratikus rendszernek a kapitalista rendszerrel szembeni előnyeit ismertették a hallgatósággal.

A választópolgárok mozgósításába természetesen a szlovákiai magyar sajtó is aktívan bekapcsolódott. Elsősorban az Új Szó, de a Szabad Földműves címü mezőgazdasági és az Új Ifjúság címü ifjúsági hetilap is rendszeresen beszámolt a választási bizottságok üléseiről, a jelölőgyűlésekröl és az agitációs központok

13 Új Szó, 1954. október 16. A dolgozók jelölteket javasolnak a Nemzetgyülésbe és a Szlovák Nemzeti Tanácsba, 1.

14 Új Szó, 1954. október 10. Csehszlovákia Kommunista Pártja Központi Bizottságának felhívása a nemzetgyűlési választások alkalmából, 1-2. 
tevékenységéröl, s közölte a kommunista párt és a Nemzeti Front említett felhívásait is. Az Új Szó és a Szabad Földmüves külön rovatot is indított, amelyben rendszeresen tájékoztatták az olvasókat többek között a választójog gyakorlásának a feltételeiröl, az egyenlő és az általános választójog, a választási névjegyzékek, a választói igazolvány, a választókerületek, a választókörzetek és a szavazócédulák mibenlétéröl. ${ }^{15}$

Az agitáció fontos elemét képezték azok a sajtócikkek, amelyek a népi demokratikus választásokat állították szembe a dualizmus kori Magyarország, vagy a két világháború közötti Csehszlovákia ,áldemokratikus” választásaival. Ez utóbbiak a sajtó szerint a korrupt burzsoá pártokat szolgálták, csakúgy, mint a kapitalista országok választásai, amelyekben a választások továbbra is a kizsákmányolás és az elnyomás eszközei. A népi demokráciákban ezzel szemben a népuralom a biztosítéka annak, hogy a képviselőjelöltek a dolgozó nép jelöltjei legyenek, hiszen maga a nép jelöli és választja meg a képviselőit, s így az arra legérdemesebbeket juttatja a parlamentbe. ${ }^{16} \mathrm{Az}$ Új Ifjúság a régi magyar országgyülés korruptságát és a korabeli választási panamákat Mikszáth Kálmán két karcolatának közlésével igyekezett illusztrálni, a Szabad Földmüves pedig Jaross Andor alakját felidézve hasonlította össze Komáromcsehi lakosainak régi és új életét. ${ }^{17}$

A választási agitációban a nemzetiségi kérdés csupán minimális teret kapott, ha mégis szó esett róla, akkor általában annak megnyugtató rendezését konstatálták. Lőrincz Gyula, az Új Szó főszerkesztője, aki maga is képviselőjelölt volt, a választások napján a lap hasábjain megjelent vezércikkében például azt emelte ki, hogy a nemzetiségek, köztük a magyarok is, megfelelö képviseletet kapnak mind a Nemzetgyülésben, mind az SZNT-ben. Azzal, hogy sok helyütt szlovákok választják meg a magyar jelölteket, másutt pedig magyarok a szlovákokat, Lőrincz szerint „elérkezett a megbékélés ideje”, amiböl egyenesen következik, hogy a választóknak erre a békére kell adniuk a szavazatukat. ${ }^{18}$

A választási törvények nem zárták ki, hogy az egyes választókerületekben akár több képviselöjelöltet is bejegyezzenek, erre azonban természetesen egyetlen választókerületben sem került sor. A jelölőgyülések lezárulta és a jelölteknek a kerületi választási bizottságok általi bejegyzése után 1954. november 2-án a nemzetgyülési választások, másnap pedig a szlovák nemzeti tanácsi választások központi választási bizottsága is azt állapíthatta meg, hogy az összes választókerületben egyetlen jelöltet jegyeztek be, egyúttal elrendelte a bejegyzett jelöltek nevének közzétételét. ${ }^{19} \mathrm{Az}$ egyes lapok, köztük az Új Szó, a következő napokban meg is kezdték a képviselöjelöltek névsorának a közlését, ${ }^{20}$ a magyar pártlap azonban ezt néhány

15 Ld. pl. Új Szó, 1954. október 15. A választási törvényt magyarázzuk. Kinek van joga választani?,

2.; Szabad Földműves, 1954. október 24, Megmagyarázzuk a választási törvényt, 2.

16 Ld. pl. Új Szó, 1954. október 17. Hogyan választanak a kapitalista országokban, 4-6.; Új Szó, 1954. október 30. Választórendszerünk demokratizmusáról, 4-5.

17 Új Ifjúság, 1954. november 13. Leleplező írások régi választásokról, 4.; Szabad Földműves, 1954. november 21. Jaross Andor nem hiányzik senkinek, 2.

18 Új Szó, 1954. november 28. Ünnepi vasárnap, 1-2.

19 Új Szó, 1954. november 5. A központi választási bizottságok üléseiröl, 2.; Új Szó 1954. november 6. A Nemzeti Arcvonal jelöltjeinek beiktatása a nép egységének jegyében, 2.

20 Ld. pl. Rudé právo, 1954. november 6. Kandidáti Národní fronty pro volby do Národního shromáždění, 3.; Pravda, 1954. november 9. Kandidáti pracujúceho l'udu Nitrianskeho kraja, 3.; Új 
nap után - bármiféle magyarázat nélkül - abbahagyta, s majd csak a választásokat követöen közölte a megválasztott képviselők teljes jegyzékét. ${ }^{21}$

A magyar képviselőjelöltek számával és kilétével a magyar sajtó nem foglalkozott. Rendszeresen beszámolt ugyan a választási gyűlésekröl, s igyekezett a jelölteket - köztük a magyarokat is - népszerüsíteni, anélkül azonban, hogy nemzetiségükre bármiféle utalást tett volna. Ráadásul a jelek szerint még a magyar nyelvü pártlap, az Új Szó szerkesztőségében sem voltak feltétlenül tisztában a jelöltek nemzetiségi hovatartozásával. Ezért fordulhatott elő akár a választási agitáció során, akár a megválasztott képviselök névsorának a közzétételekor, hogy a lap a szlovák nemzetiségü képviselöjelöltek, illetve megválasztott képviselök nevét magyarul, ${ }^{22} \mathrm{a}$ magyarokét ugyanakkor esetenként szlovákul szerepeltette. ${ }^{23}$ Ebben nyilván közrejátszhatott a reszlovakizált magyarok nagy száma és gyakran problémás nemzetiségi besorolásában is, aminek következtében nehéz volt eligazodni abban a kérdésben, hogy ki is számít közülük magyar, s ki szlovák nemzetiségűnek.

A jelöltek bemutatásának visszatérő eleme volt munkáscsaládból való származásuk, nélkülözésben telt gyermekkoruk, a „kulákok” általi kizsákmányolásuk, munkásmozgalmi múltjuk, a szövetkezetesítésben való részvételük hangsúlyozása, valamint munkasikereik és kitüntetéseik felsorolása, amelyekkel sikerült elnyerniük a nép bizalmát. Lőrincz Gyula és Dénes Ferenc személye közéleti munkásságukból adódóan meglehetősen ismert volt, így az ő bemutatásukkal a sajtó különösebben nem foglalkozott, a többi képviselöjelölt népszerüsítésére ezzel szemben már nagyobb figyelmet fordítottak. Árvay Józsefről, aki 1921-ben a kommunista párt alapító tagjai közé tartozott, a sajtó megírta, hogy „,nemcsak a felszabadulás után, de a múltban is a munkásosztály és a parasztság érdekeit védte, amikor a csendörszuronyok között kellett küzdeniök. Sok megpróbáltatáson ment keresztül, de mindig hüségesen kiállt a kizsákmányoltak érdekében." ${ }^{44}$ Trencsik Jánosról, aki a harmincas években a komáromi pártszervezet elnöke és komáromi városi képviselő volt, megtudhatta az olvasó, hogy 1918-ban ,edződött a vörös igazság kemény harcosává s a dolgozó nép érdekeinek védelmezőjévé a kizsákmányolókkal szemben". ${ }^{25}$

Szeifert Ferenc, a bajcsi állami gazdaság kombájnosa többek között azzal érdemelte ki a képviselőjelöltséget, hogy 1954-ben több mint 430 hektárt aratott le és csaknem 90 vagon gabonát csépelt ki, amivel az ország legjobb kombájnosa lett. ${ }^{26} \mathrm{Az}$ ország első női kombájnosaként számon tartott, s 1953-ban „Az építésben szerzett érdemekért” kitüntetéssel, 1954-ben pedig Csehszlovák Békedíjjal jutalmazott Szigl Máriáról megírták, hogy 228 hektárt aratott le, amivel az éberhárdi

Szó, 1954. november 10. A Nemzeti Arcvonal jelöltjei a nemzetgyülésbe, 2.

21 Új Szó, 1954. december 3. A nemzetgyülési választások eredményei az egyes kerületekben,

5-6.; Új Szó, 1954. december 4. A Szlovák Nemzeti Tanácsba való választások eredményei az egyes kerületekben, 5 .

22 PI. Pavol Lúč/Lúcs Pál, Štefan Cap/Cap István, Anna Molnárová/Molnár Anna, Štefan Livinka/

Livinka István.

23 PI. Szeifert Ferenc/František Seifert, Petrás Gabriella/Gabriela Petrášová, Stromp József/Jozef Štromp.

24 Új Szó, 1954. november 28. Egységesen szavazunk jelöltjeinkre, 3.

25 Szabad Földműves, 1954. november 14. A komáromi járás két jelöltje, 3.

26 Szabad Földműves, 1954. október 10. Seifert kiváló kombájnos, képviselőjelölt, 8. 
traktoros brigád kombájnosainak élére került. ${ }^{27} \mathrm{~A}$ Munkaérdemrenddel kitüntetett kőművesről, Török Pálról kiderült, hogy „,az új munkamódszerek bevezetésének úttörője”. Az általa vezetett munkacsoport vállalta, hogy december 19-ig - Antonín Zápotocký köztársasági elnök születésnapjáig - 440 lakásnak végzi el a durva kivakolását. Az első tíz hónap alatt „már 342 lakást adtak át készen a lakóknak, így megvan az elöfeltétel arra, hogy kötelezettségvállalásukat tudják teljesíteni a pontos határidöre". ${ }^{28}$

Pollák Lajos, Vrábel Vendel, Brandics András és Dobos Imre szövetkezeti elnökökröl a sajtó egyaránt közölte, hogy elsőkként léptek be a szövetkezetbe. A Pollák által vezetett felsőpatonyi szövetkezet „megalakítása óta 600 sertés számára hizlaldát, szarvasmarha részére istállót, gabonaraktárakat, szövetkezeti mühelyt és további fontos gazdasági épületeket” állított fel. ${ }^{29}$ Vrábel imelyi szövetkezetében „az új, korszerü sertés- és marhaistálló, dohányszárító mellett most nagy magtár épül”, Brandics András mokcsakerészi szövetkezete pedig a Nagykaposi járás legjobb szövetkezetei közé tartozik. ${ }^{30}$ A Dobos által vezetett leleszi szövetkezet „korszerü, hosszú sertéshizlaldát, lóistállót, anyakoca-nevelőt, juhistállót, 5 marhaistállót, tyúkfarmot, 3 dohányszárítót, kultúrházat" épített. ${ }^{31}$ A leleszi szövetkezet másik képviselőjelöltjének, a Kassai kerület legfiatalabb jelöltjének, Berta János traktoros brigádvezetőnek köszönhető, hogy a szövetkezet a Királyhelmeci járásban az első helyen áll az őszi munkálatokkal. „A fiatal brigádvezető ezeket a jó eredményeket a szovjet tapasztalatok felhasználásával éri el" - hangsúlyozta az Új Szó. ${ }^{32}$

Tóth Imre, a kenyheci szövetkezet könyvelöje a Szabad Földmüves szerint „szorgalmasságával és lelkiismeretességével elnyerte a kerület legjobb könyvelőjének hírét", a szövetkezet pedig a Kassai járás legjobb szövetkezeteinek egyike. A szövetkezet tagjai „gabonabeszolgáltatásukat 178 métermázsával teljesítették túl s az állati termékek beadását október végéig 160 százalékra teljesítették". ${ }^{33}$ Csank Jenöröl, a gesztetei helyi nemzeti bizottság és a szövetkezet elnökéröl az Új Szó és a Szabad Földmüves egyaránt megírta, hogy nagy érdemei vannak szülöfaluja felvirágoztatásában, s felidézték a falubeliek emlékeit, akik szerint a község másik szülötte, gróf Putnoky Móric, a magyar országgyülés egykori képviselője csak azért járt el a faluba, hogy birtokai jövedelmét összeszedje. ${ }^{34}$

Az 1954. november 28-i parlamenti választások - a pártvezetés elvárásainak megfelelően - a Nemzeti Front nagyarányú sikerével végződtek. A semmiféle ellenzék létét és választási indulását, sem pedig a kiválasztott jelöltekkel szembeni ellenpropagandát nem türő pártállami keretek és az ország lakosságának megfé-

27 Új Szó, 1954. november 13. Példás munkával nyerte el a nép bizalmát, 1.

28 Új Szó, 1954. október 3. Dolgozó népünk jelöltjei a Nemzetgyülésbe és a Szlovák Nemzeti Tanácsba, 2.; Új Ifjúság, 1954. november 13. Török Pálról, 3.

29 Szabad Földműves, 1954. november 14. Szövetkezeti elnök, jelölt a Nemzetgyűlésbe, 3.

30 Új Szó, 1954. november 4. Vrábel Vendel, az imelyi szövetkezet elnöke, 1.; Új Szó, 1954. november 6 . Mokcsakerésztöl Leleszig, 3.

31 Új Szó, 1954. november 2. Igyekezni fog a nép bizalmát kiérdemelni, 3.

32 Új Szó, 1954. november 6. Mokcsakerésztől Leleszig, 3.

33 Szabad Földműves, 1954. november 14. Tóth Imrét, a kenyheci EFSz könyvelőjét jelölték a Szlovák Nemzeti Tanácsba, 2.

34 Új Szó, 1954. november 11. A helyi nemzeti bizottság elnöke a nemzetgyülés képviselőjelöltje, 1.; Szabad Földműves, 1954. november 21. Gróf Putnoky Mórictól Csank Jenőig, 3. 
lemlítettsége mellett más eredményre természetesen nem is lehetett számítani. A hatalom a választóktól ráadásul azt is elvárta, hogy a szavazás során a választóhelyiségben felállított spanyolfalat se vegyék igénybe, hanem a szavazólapot a választási bizottság szeme láttára tegyék a boritékba és dobják a választási urnába. A spanyolfal igénybevétele a jelölt nevének áthúzására, azaz ellenszavazat leadására adott volna lehetöséget, ezért a spanyolfal mögé félrevonulóknak a hatalom esetleges retorziójával kellett számolniuk (Krejči 2006, 246).

1. kép: Az Új Szó fejléce a választások napján, 1954. november 28-án

\section{Egységhen a hazéért, a szocializmusért, a békéért! \\ Világ proletárjai egyesiljjetek!
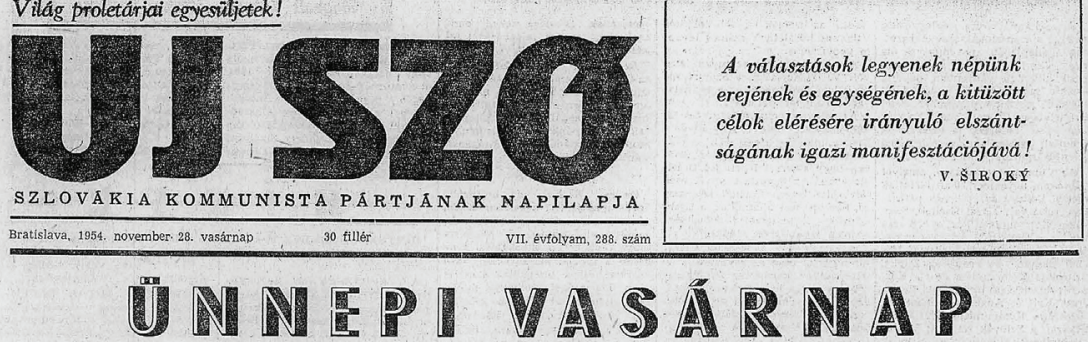

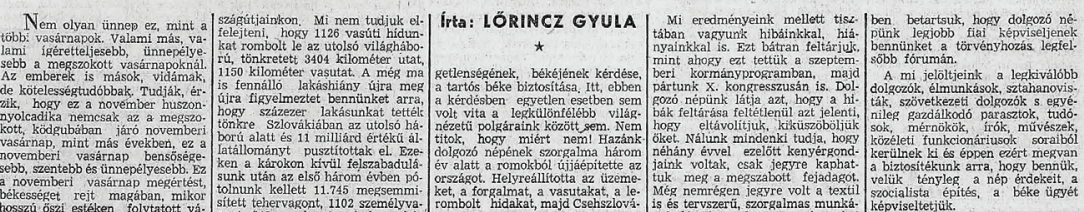

A propaganda a kedvező választási eredményt mindemellett természetesen igyekezett kiaknázni és a társadalomnak a kormány és a kommunista párt mögötti egységes felsorakozásával magyarázni. A sajtó hemzsegett a győzelmi jelentésektől. Az Új Szó november 29-i számának címlapja például „Szabad hazánkra, békés, boldog életünkre szavaztunk!”, a Szabad Földmüves december 5-i száma pedig „Dolgozó népünk nagy lelkesedéssel, szilárd egységben szavazott" címmel számolt be a választásokról. ${ }^{35}$ A központi prágai pártlap, a Rudé právo az Új Szó által is átvett, „Népünk dicső győzelme” címü vezércikkében méltatta a választások eredményét. Az írás szerint „a Nemzetgyűlésbe és a Szlovák Nemzeti Tanácsba való választások vasárnap újból világosan megmutatták népünk hatalmas egységét, a kommunista párt köré való felzárkózását, a Nemzeti Front gondolatához való hűségét, amely az összes becsületes gondolkodású polgárokat egybekapcsolja; újból bebizonyították a munkások és a dolgozó parasztok szövetségének erejét és szilárdságát, amely rendszerünk megrendíthetetlen alapját képezi." 36

A nemzetgyülési választások központi választási bizottsága által kihirdetett hivatalos végeredmény szerint a nemzetgyülési választásokon 8711718 választópolgár,

35 Új Szó, 1954. november 29. 1.; Szabad Földműves, 1954. december 5. 2.

36 Rudé právo, 1954. november 29. Slavné vítězství lidu, 1.; Új Szó 1954. november 30. Népünk dicső győzelme, 1. 
vagyis a bejegyzett választók 99,2\%-a vett részt. Érvényes szavazatot 8677030 fö, azaz 99,6\%-uk adott le, az érvényes szavazatot leadók közül pedig 8494102 fö, vagyis 97,9\%-uk megszavazta a Nemzeti Front jelöltjeit, s csupán 182 928-an $(2,1 \%)$ szavaztak ellenük. ${ }^{37}$ Ezzel csaknem azonos eredmények születtek a szlovák nemzeti tanácsi választásokon is. A választások központi választási bizottsága szerint a választásokon 2324279 választópolgár, vagyis a szavazásra jogosultak 99,1\%-a vett részt. Érvényes szavazatot 2312658 fö, azaz 99,5\%-uk adott le. Az érvényes szavazatot leadók közül 2249547 fö, vagyis 97,3\%-uk megszavazta a Nemzeti Front jelöltjeit, ellenük pedig csupán 63111 fő, azaz 2,7\%-uk szavazott. ${ }^{38}$

A Nemzetgyülés alakuló ülésére 1954. december 13-án, a Szlovák Nemzeti Tanács alakuló ülésére pedig december 18-án került sor. A két testület Mandátumvizsgáló Bizottságainak jelentései - 1945 óta első ízben - ismertették a két parlament képviselöinek nemzetiségi összetételét is. Ezek szerint a Nemzetgyülésben 253 cseh, 98 szlovák, 9 magyar 3 ukrán, 3 német és 2 lengyel, az SZNT-ben pedig 85 szlovák, 13 magyar, 3 cseh és ugyancsak 3 ukrán nemzetiségü képviselő kapott helyet. A Nemzetgyűlés Mandátumvizsgáló Bizottságának előadója, Jan Vodička szerint a testület nemzetiségi összetétele „,nemzeteink testvéri szövetségének” a megnyilvánulása, az SZNT bizottsági előadója, Jozef Tokár pedig azt hangsúlyozta, hogy ez az összetétel „teljesen megfelel a nemzetiségi politika lenini-sztálini alapelveinek". ${ }^{39}$

A képviselői helyek túlnyomó többsége, közel háromnegyede, természetesen mindkét parlamentben a kommunistáknak jutott. A 368 fős Nemzetgyülésben a CSKP és az SZLKP együttesen 262, a Csehszlovák Szocialista Párt és a Csehszlovák Néppárt 20-20, a Szlovák Megújhodás Pártja 6, a Szabadságpárt 4 képviselői helyet kapott, 56 képviselő pártonkívüli volt. A 104 tagú SZNT-ben az SZLKP-nak 77, a Szlovák Megújhodás Pártjának 10, a Szabadságpártnak 5 képviselője lett, további 12 képviselő pártonkívüliként kapott mandátumot. A két törvényhozó testület összesen 22 magyar nemzetiségü képviselője közül mindössze 4-en (Petrás Gabriella, Pongrácz Frigyes, Török Pál és Vida Irma) voltak pártonkívüliek, a többiek mindnyájan a kommunista párt képviselőjeként kerültek a parlamentekbe. A két további szlovák párt, a Szlovák Megújhodás Pártja és a Szabadságpárt sem 1954ben, sem a későbbiekben nem juttathatott be magyar képviselőket a két törvényhozásba. Magyar nemzetiségűek csakis a kommunista párt színeiben vagy pedig pártonkívüliként kaphattak parlamenti mandátumot.

A Nemzetgyülés 1954. december 14-én és az SZNT december 18-án elfogadott ügyrendi törvénye - 1945 óta ismét csak első ízben - egyaránt kimondta, hogy minden képviselőnek joga van saját anyanyelvén beszélnie. ${ }^{40}$ Az 1945 utáni

37 Új Szó, 1954. december 2. A nemzetgyülésbe való választások központi választási bizottságának jelentése, 6 .

38 Új Szó, 1954. december 3. A Szlovák Nemzeti Tanácsba való választások központi választási bizottságának jelentése, 4.

39 Digitální knihovna, NS RČS 1954-1960, Těsnopisecká zpráva o 3. schůzi Národního shromáždění republiky Československé v Praze ve středu dne 14. prosince 1954, https://www.psp.cz/eknih/; Stenografická zpráva o priebehu ustavujúcej (1.), 2. a 3. schôdzky Slovenskej národnej rady z 18. decembra 1954 v Bratislave, 33.

40 Sbírka zákonů Republiky československé. Ročník 1954, částka 39., 223-228.; Zbierka zákonov Slovenskej národnej rady. Ročník 1954, čiastka 7., 41-46. 
parlamentek ügyrendi törvényei ezt a kérdést jobb esetben nem szabályozták, de előfordult, hogy egyenesen kimondták, miszerint a tárgyalási nyelv a cseh és a szlovák. Az új szabályozás tehát mindenképpen elörelépést jelentett a korábbiakhoz képest. Az SZNT ügyrendi törvényének előadója, Pavol Dubovský mindezt a „,nemzetiségi politika sztálini érvényesítésének" tulajdonította, ${ }^{41}$ elmulasztva természetesen hozzátenni, hogy ezt a jogot biztositották már az első Csehszlovák Köztársaság törvényhozásában, sőt a háború alatti szlovák állam országgyülésében is.

Az SZNT alakuló ülésén Dénes Ferencet beválasztották a testület 11 fös Elnökségébe, s megválasztották az SZNT egyik alelnökévé is. Ezt követően a szlovák parlamentnek az 1989-es rendszerváltásig csaknem mindig volt legalább egy magyar elnökségi tagja, s az 1960-1968 közötti évek kivételével magyar nemzetiségü alelnöke is. ${ }^{42}$ Az Elnökség összetételének elözményeihez tartozik, hogy a szlovák pártvezetés kezdetben nagyobb létszámú, 15 fös Elnökségben gondolkodott, amelyben Janó Károly személyében egy további magyar képviselő is helyet kapott volna. Az erre vonatkozó javaslatot azonban 1954. november 20-án az SZLKP KB Irodája elvetette, a november 28-án jóváhagyott 11 fős Elnökségben pedig már csak egyetlen magyarral, Dénes Ferenccel számoltak. ${ }^{43}$

Az SZNT magyar nemzetiségü képviselőit - Dénes Ferenc kivételével - beválasztották valamelyik parlamenti bizottságba is. A Földmüvelésügyi Bizottságban Berta János, Janó Károly, Pongrácz Frigyes és Szeifert Ferenc, a Gazdasági és Költségvetési Bizottságban Brandics András, Prokos József és Török Pál, a Kulturális és Népművelési Bizottságban Árvay József és Vida Irma, a Jogi Bizottságban Nagy István és Tóth Imre, a Mandátumvizsgáló Bizottságban pedig Trencsik János kapott helyet. ${ }^{44}$ Dénes a parlament alelnökeként - az SZNT többi alelnökéhez hasonlóan - egyik bizottságnak sem lett a tagja.

A Nemzetgyülés 9 magyar képviselöje a 368 fös testületben csupán marginális szerepet tudott betölteni. A prágai parlamentben nemcsak magyar alelnököt, hanem magyar elnökségi tagot sem választottak. Igaz, a következő választási időszakban némi pozitív változás történt ezen a téren, s 1960-tól kezdődően, ha magyar alelnöke nem is, de magyar elnökségi tagja már rendszeresen lett a testületnek. A képviselök nagy számából adódóan bizottsági tagság sem jutott az összes magyar képviselönek. Lőrincz Gyula és Petrás Gabriella a Kulturális Bizottság, Pollák Lajos az Egészségügyi Bizottság, Porubszky Béla a Földművelésügyi Bizottság, Stromp József pedig egyszerre két bizottságnak, a Költségvetési és Gazdasági Bizottságnak, valamint a Földművelésügyi Bizottságnak is a tagja lett, Csank Jenőt, Dobos Imrét, Szigl Máriát és Vrábel Vendelt ugyanakkor egyetlen bizottságba sem választották be. ${ }^{45}$

Annak természetesen a legcsekélyebb esélye sem volt, hogy a két parlament magyar nemzetiségü képviselői valamiféle kisebbségi érdekképviseleti tevékeny-

41 Stenografická zpráva o priebehu ustavujúcej (1.), 2. a 3. schôdzky Slovenskej národnej rady z 18. decembra 1954 v Bratislave, 30-31.

42 Az SZNT további magyar nemzetiségü alelnökei a pártállami években Szabó Rezső (1968-1970), Fábry István (1970-1976), Benyó Máté (1976-1983) és Krocsány Dezső (1983-1989) voltak. 43 SNA, ÚV KSS - Preds., 878. k., a. j. 44.; a. j. 46.

44 Stenografická zpráva o priebehu ustavujúcej (1.), 2. a 3. schôdzky Slovenskej národnej rady z 18. decembra 1954 v Bratislave, 30-31.; vö. Rákoš - Rudohradský 1973. 473-474.

45 Digitální knihovna, NS RČS 1954-1960, Těsnopisecká zpráva o 3. schůzi Národního shromáždění republiky Československé v Praze ve středu dne 14. prosince 1954, https://www.psp.cz/eknih/ 
séget folytassanak. A pártvezetés nem is ezzel a feladattal juttatta öket a törvényhozásba, hanem azzal, hogy ottlétükkel demonstrálják, felszólalásaikkal pedig alátámasszák a kommunista párt helyes nemzetiségi politikáját, amely a számarányának megfelelő képviseletet biztosít az ország összes nemzetisége számára. A parlamentek tevékenysége egyébként is formális volt, az üléseken valódi, érdemi vita nem zajlott, az ülések elöre megrendezettek, a hozzászólások elöre jóváhagyottak voltak. A képviselők szerepe gyakorlatilag a kormány és a kommunista párt politikájának dicséretére, az előterjesztett jelentések és törvénytervezetek kötelező jóváhagyására korlátozódott.

Érvényes volt mindez a parlamentek többségi képviselöire, de talán még hatványozottabban a magyar nemzetiségüekre. Az SZNT 13 magyar képviselöje a választási időszak hat éve alatt összesen mindössze tizennégy alkalommal szólalt fel, s egy alkalommal volt valamely törvénytervezet bizottsági előadója. A Nemzetgyülés 9 magyar képviselöje közül ráadásul egyedül Lörincz Gyula szólalt fel, ő is mindössze két alkalommal, s további egy alkalommal volt bizottsági előadó. Az SZNT magyar képviselői közül Brandics András, Prokos József, Szeifert Ferenc és Vida Irma, a Nemzetgyűlés magyar képviselői pedig - Lőrincz kivételével - mindnyájan anélkül ülték végig a hat éves megbízatási időszakot, hogy a parlament ülésein akár csak egyetlen alkalommal is felszólaltak volna.

A két törvényhozó testület 1954-ben megválasztott magyar nemzetiségű képviselöinek történetéhez tartozik, hogy amíg az SZNT képviselői megbízatásuk végéig, azaz 1960-ig mindnyájan megtartották a mandátumukat, a Nemzetgyülés egyik képviselője, Szigl Mária 1957 márciusában lemondott a parlamenti mandátumáról. A magyar képviselők száma azonban ezzel nem változott, mivel az 1957. május 19én megtartott pótválasztások során a 289. számú választókerületben - amelyben 1954-ben Sziglt is megválasztották - Fehér Zdenkát, a somorjai efsz dolgozóját indították és választották képviselővé, aki a Nemzetgyűlés legközelebbi, 1957. július 4-i ülésén le is tette a képviselöi esküt. ${ }^{46}$

Az 1960-ban kezdődő új választási ciklusban az SZNT magyar képviselői közül Dénes Ferenc, Szeifert Ferenc, Tóth Imre és Vida Irma ismét helyet kapott a szlovák parlamentben. Képviselő maradt Árvay József és Berta János is, számukra azonban a továbbiakban már nem a pozsonyi, hanem a prágai törvényhozásban biztositottak mandátumot. A Nemzetgyűlés magyar képviselöit ugyanakkor - Lőrincz Gyula kivételével - teljes egészében lecserélték. A pótválasztásokon megválasztott Fehér Zdenka egy jó évtized elteltével, 1971-ben, ezúttal már az SZNT képviselőjeként tért vissza a parlamentbe.

Az 1954-es választásoktól kezdődően a pártállam 1989-es bukásáig bevett gyakorlattá vált, hogy a magyar kisebbség számára - akárcsak a többi kisebbség, az egyes pártok és társadalmi csoportok számára - elöre megállapított kvóta szerint biztositottak képviseletet a két törvényhozásban. A magyar nemzetiségű képviselők aránya általában megfelelt a magyar kisebbség összlakosságon belüli részarányának. A magyar képviselök mindazonáltal nem a magyar kisebbségi közösség, ha-

46 Digitální knihovna, NS RČS 1954-1960, Těsnopisecká zpráva o 19. schůzi Národního shromáždění republiky Československé v Praze ve čtvrtek 4. a v pátek 5. července 1957, https://www.psp. cz/eknih/ 
nem a pártvezetés által kiválasztott és parlamentbe juttatott, a pártállam nemzetiségi politikájának helyességét és eredményeit demonstrálni hivatott személyek voltak, akiknek a magyar kisebbség érdekeinek megjelenítésére és sérelmeinek szóvá tételére vajmi kevés lehetöségük nyilt. ${ }^{47}$

\section{Források és irodalom}

\section{Levéltári források}

Slovenský národný archív, Bratislava (Szlovák Nemzeti Levéltár, Pozsony)

fond: Ústredný výbor Komunistickej strany Slovenska - Predsedníctvo

\section{Forráskiadványok}

Stenografická zpráva o priebehu ustavujúcej (1.), 2. a 3. schôdzky Slovenskej národnej rady z 18. decembra 1954 v Bratislave

\section{Jogforrások}

Sbírka zákonů Republiky československé 1954

Zbierka zákonov Slovenskej národnej rady 1954

\section{Internetes forrás}

Digitální knihovna. https://www.psp.cz/eknih/

\section{Korabeli sajtó}

Pravda (Pozsony) 1954

Rudé právo (Prága) 1954

Szabad Földmüves (Pozsony) 1954

Új Ifjúság (Pozsony) 1954

Új Szó (Pozsony) 1954 


\section{Szakirodalom}

Krejči, Oskar (2006): Nová kniha o volbách. Praha: Professional Publishing.

Krivý, Vladimír - Zemko, Milan (2008): Vol'by do zákonodarných orgánov na území Slovenska 1920-2006. Bratislava: Štatistický úrad Slovenskej republiky.

Pešek, Jan a kol. (2003): Aktéri jednej éry na Slovensku 1948-1989. Personifikácia politického vývoja. Prešov: Vydavatel'stvo Michala Vaška.

Popély Árpád szerk. (2014): Iratok a csehszlovákiai magyarság 1948-1956 közötti történetéhez II. Válogatás a prágai magyar követség és a pozsonyi magyar fökonzulátus magyar kisebbséggel kapcsolatos jelentéseiből. Somorja: Fórum Kisebbségkutató Intézet.

Rákoš, Elo - Rudohradský, Štefan (1973): Slovenské národné orgány 1943-1968. Bratislava: Slovenská archívna správa. 